\title{
Células-tronco em Odontologia
}

\author{
Ana Prates Soares*, Luégya Amorim Henriques Knop*, Alan Araujo de Jesus **, Telma Martins de Araújo**
}

\begin{abstract}
Resumo
Introdução: existe um grande interesse no desenvolvimento de técnicas para a manipulação de células-tronco, no intuito de instituirem-se tratamentos restauradores de tecidos e órgãos. Para que a bioengenharia seja eficaz, faz-se necessária a presença de três fatores: as próprias células-tronco, uma matriz extracelular e fatores de crescimento. Existem inúmeros fatores de crescimento envolvidos no desenvolvimento do órgão dentário. Por isso pesquisadores ainda não foram capazes de formar um órgão completo, embora existam diversos estudos evidenciando a formação de esmalte e dentina a partir de células-tronco isoladas da polpa dentária. Recentemente, também foram isoladas células-tronco da polpa dos dentes decíduos. Sabe-se que estas células são altamente proliferativas, sendo de grande importância para o cirurgiãodentista o conhecimento do seu comportamento biológico e técnicas de obtenção. Objetivo: este estudo teve como objetivo realizar uma revisão de literatura acerca das atuais tendências das pesquisas com células-tronco na Odontologia, além de discorrer sobre os fatores implicados para o sucesso na utilização prática dessas células.
\end{abstract}

Palavras-chave: Células-tronco. Bioengenharia. Pesquisa em Odontologia.

\section{INTRODUÇÃO}

A perda dentária e dos tecidos periodontais pode resultar em movimento dos dentes remanescentes, dificuldade na mastigação, fonação, desequilíbrio na musculatura e comprometimento da estética dentária e do sorriso, comprometendo a auto-estima. Atualmente existem diversas terapias para substituição dos órgãos dentários, todas elas baseadas em técnicas não-biológicas e sujeitas a falhas ${ }^{26}$. Apesar desta condição ser uma anormalidade comum e não ameaçar a vida do paciente, esforços têm sido dirigidos para o desenvolvimento de mecanismos para a utilização de células-tronco na reposição de tecidos bucais ${ }^{12}$.

Para a bioengenharia é essencial uma tríade composta por células-tronco ou progenitoras, uma matriz que funcione como arcabouço e proteínas sinalizadoras, denominadas fatores de crescimento, como estímulo para diferenciação celular (Fig. 1).

O objetivo desta revisão de literatura foi discorrer acerca das técnicas da bioengenharia e relatar os resultados obtidos nos experimentos com células-tronco, bem como suas reais tendências na aplicação em Odontologia.

* Acadêmicas do Curso de Graduação em Odontologia - UFBA

** Especialista em Prótese Dental (ABO/Ba). Mestre em Odontologia (FOUFBA). Doutorando em Biotecnologia UEFS/FIOCRUZ.

*** Doutora e Mestre em Ortodontia - UFRJ. Professora Titular de Ortodontia UFBA. Diplomada pelo Board Brasileiro de Ortodontia e Ortopedia Facial. 


\section{CÉLULAS-TRONCO OU PROGENITORAS}

Células-tronco são definidas como células indiferenciadas com grande capacidade de auto-renovação e de produzir pelo menos um tipo celular altamente especializado. Existem duas categorias de células-tronco: as células-tronco embrionárias pluripotentes e a linhagem de células unipotentes ou multipotentes, denominadas células-tronco adultas, que residem em tecidos diferenciados ${ }^{22}$.

A maior vantagem do uso de células-tronco embrionárias é a sua capacidade de proliferação e de diferenciação em diversos tipos celulares. Mas existem desvantagens, como a sua instabilidade genética, a obrigatoriedade de sua transplantação para hospedeiros imunocomprometidos, o risco de formação de teratocarcinomas e de contaminação através do seu cultivo em fibroblastos de ratos $^{22}$, além da questão ética ${ }^{18}$. A viabilidade do uso de células-tronco adultas na regeneração e reconstrução de tecidos tem suscitado grande interesse na comunidade científica, dado o aumento de leis em diversos países que proíbem o uso de células-tronco embrionárias em pesquisas ${ }^{24}$.
Já as células-tronco adultas apresentam a vantagem de serem autogênicas, não incorrendo em limitações morais, e responsivas aos fatores de crescimento inerentes ao hospedeiro. No entanto também apresentam desvantagens, como o fato de não serem pluripotentes, a dificuldade de obtêlas, purificá-las e cultivá-las in vitro, além de sua presença em menor quantidade nos tecidos ${ }^{24}$. A principal fonte de células-tronco adultas é a medula óssea. Estas células têm a capacidade de se diferenciarem em células dos tecidos ósseo, adiposo, cartilaginoso e muscular, o que demonstra sua alta plasticidade ${ }^{9}$.

Inúmeros estudos têm isolado células altamente proliferativas, derivadas da polpa dentária $^{3,8,18,19,20,27}$. Constatou-se que tais células são multipotentes e possuem a capacidade de autorenovação e de diferenciação em diversos tipos celulares. Foi observada uma conversão fenotípica destas células, através da expressão de proteínas adiposas (PPAR $\gamma 2$, sigla do inglês peroxisome proliferator activated receptor $\gamma 2$, e a lipoproteína lipase), após o estímulo por um meio de

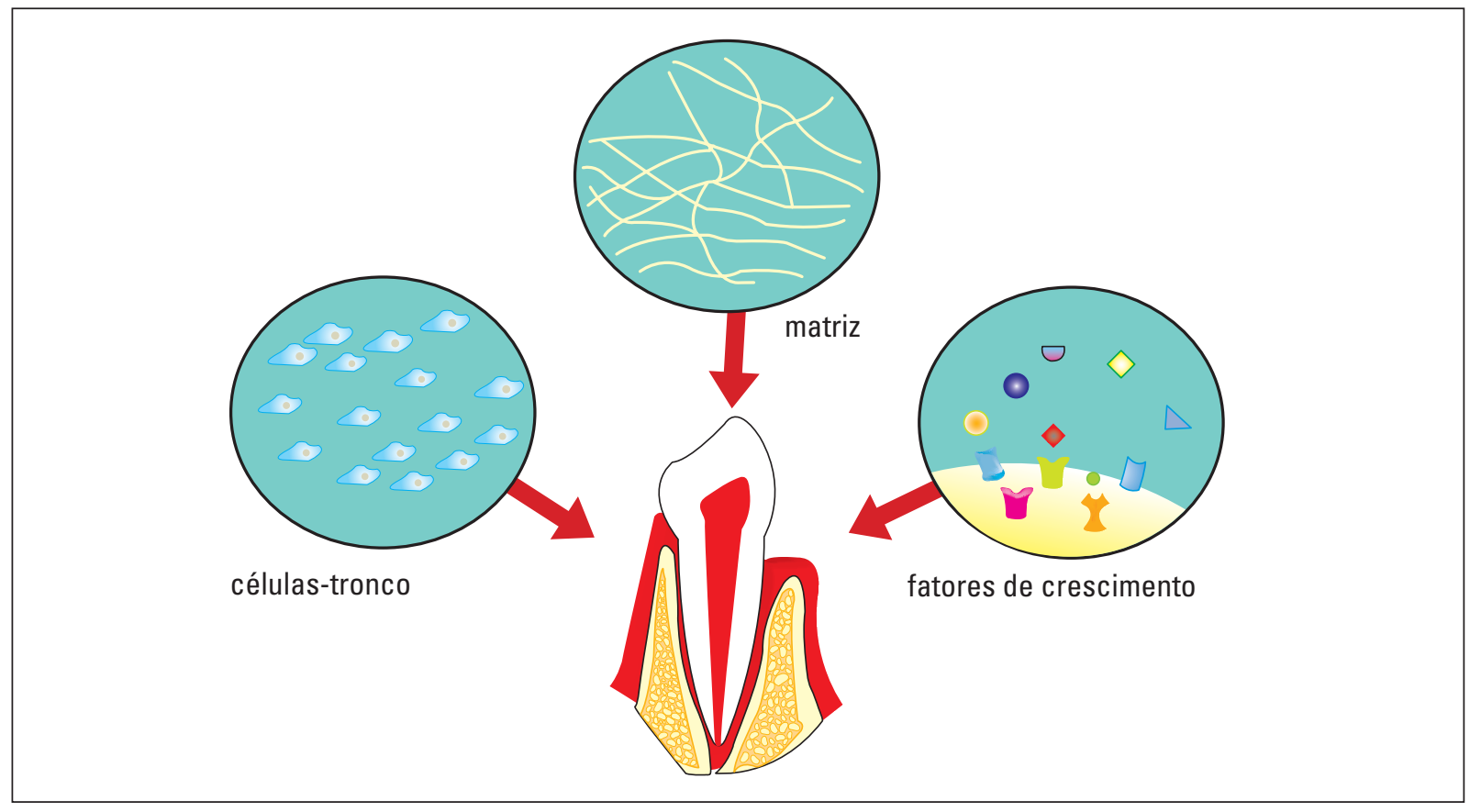

FIGURA 1 - Fatores necessários para a bioengenharia na Odontologia. 
cultura com alto potencial indutivo adipogênico. Ademais, as células-tronco da polpa dentária expressaram nestina e proteína glial fibrilar ácida (GFAP, sigla do inglês glial fibrilar acid protein), que são marcadores de precursores neurais e células gliais, respectivamente ${ }^{7}$.

Existem evidências de que células-tronco de dentes decíduos são similares àquelas encontradas no cordão umbilical. Quando comparadas às células-tronco provenientes da medula óssea e da polpa de dentes permanentes, notou-se que as SHED (stem cells from human exfoliated deciduous teeth) apresentam uma maior taxa de proliferação. Além disso, os dados desse estudo indicam que as SHED possuem habilidade de se diferenciarem em células odontoblásticas funcionais, adipócitos e células neurais, além de estimularem a osteogênese após transplantação in vivo (Fig. 2) ${ }^{16}$.

Pesquisas demonstraram que células-tronco da polpa requerem um meio indutor apropriado e um arcabouço composto por hidroxiapatita/tricálciofosfato para induzir a formação de osso, cemento e dentina in vivo ${ }^{3,8}$. Alguns autores demonstraram a formação de tecido ósseo fibroso autólogo a partir de células-tronco provenientes de polpas de indivíduos com idades acima de 30 anos, assim como a diferenciação dessas células em odontoblastos ${ }^{11}$.

Os marcadores para as células-tronco são de extrema importância, pois estas células residem em diferentes locais dentro do tecido ${ }^{26}$. São necessários mais estudos sobre marcadores específicos que possam identificar nichos de células-tronco presentes na polpa dentária in situ e sobre como se dá o desenvolvimento desses nichos ${ }^{9}$. É possível que as células-tronco da polpa humana e do ligamento periodontal estejam associadas com a microvasculatura $^{8,25}$. Atualmente são utilizados os seguintes marcadores microvasculares, para localização de tais células: STRO-1 (marcador de células do estroma), Fator Von Willebrand e CD146 (molécula da superfície de células endoteliais) ${ }^{18,25,26}$. A expressão da telomerase celular em tecidos normais parece estar associada à presença de células-tronco. Técnicas de detecção in situ dessa ribonucleoproteína têm a possibilidade de atuarem como marcadores celulares ${ }^{9}$.

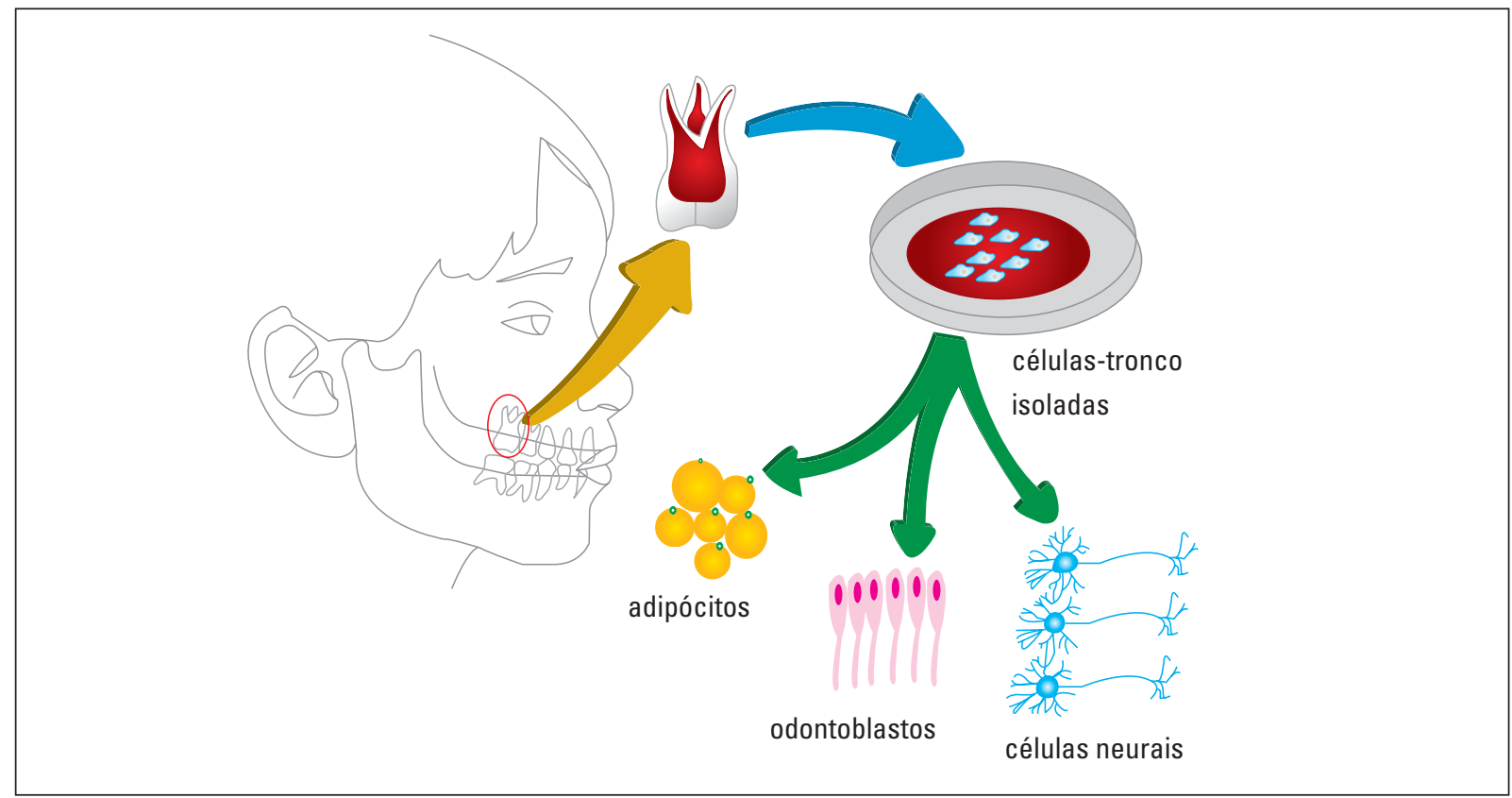

FIGURA 2 - Células-tronco isoladas do tecido pulpar de dentes decíduos têm alta capacidade proliferativa e são capazes de se diferenciarem em odontoblastos maduros, adipócitos ou células neurais. 
Pesquisadores cultivaram células-tronco da medula óssea e da polpa humana, provenientes de terceiros molares impactados, e analisaram a expressão genética dessas células, através do método cDNA Microarray. Foi demonstrado um padrão gênico altamente similar entre esses dois tipos celulares, com exceção de alguns genes, incluindo o IGF-2 (fator de crescimento insulínico-2, sigla do inglês insulinic growth factor-2) e colágeno tipo XVIIIal, no entanto ainda é desconhecida a expressão dessa diferença ${ }^{27}$.

\section{MATRIZ}

Para bioengenharia de tecidos, uma matriz é essencial, pois fornece o arcabouço necessário para o transporte de nutrientes, oxigênio e resíduos metabólicos. Esse arcabouço deve ser biocompativel, não irritante e resistente. A matriz é composta por materiais sintéticos ou naturais ${ }^{18}$. Os componentes da matriz funcionam ativando morfogenes das células implantadas ${ }^{19,20}$, enquanto esta é gradualmente degradada e substituída pelo tecido regenerado ${ }^{19}$. Para a formação de tecido dentário têm sido utilizadas as matrizes PGA (ácido poliglicólico, sigla do inglês polyglycolic acid) ${ }^{6,10}$ e PLGA (ácido poli co-glicolídeo copolímero, sigla do inglês poli co-glycolide copolymer), ambas apresentando similaridade no suporte de crescimento de tecidos dentários altamente organizados ${ }^{6}$.

Também pode ser usado um sistema de matriz com a configuração tri-dimensional, a partir do colágeno tipo I, para o cultivo de células-tronco em experimentos, visando sua diferenciação em odontoblastos $^{5}$. Neste estudo objetivou-se avaliar a resposta de células-tronco provenientes do primeiro arco branquial de ratos ao estímulo por TGF-ß1 (sigla do inglês transforming growth factor ß1) e DNCP (proteína não-colagênica da matriz extracelular dentária, sigla do inglês dentin non colagenic protein) através da expressão de proteínas características de odontoblastos. Apenas no grupo tratado somente com fator de crescimento TGF-ß1 não houve a formação de tecido semelhante ao com- plexo dentino-pulpar, sugerindo que proteínas derivadas da matriz extracelular desempenham uma função essencial na diferenciação odontoblástica.

Fibroblastos isolados a partir da polpa dentária foram cultivados em matriz composta por fibras de ácido poliglicólico e, após 60 dias, exibiram celularidade similar à encontrada na polpa humana normal, indicando que esta matriz apresenta boas propriedades para a bioengenharia ${ }^{17}$.

\section{FATORES DE CRESCIMENTO}

A morfogênese dentária envolve uma série de interações dinâmicas e recíprocas entre o ectoderma e o mesênquima ${ }^{29}$. Os fatores de crescimento são proteínas secretadas extracelularmente que governam a morfogênese durante tais interações e compreendem cinco famílias protéicas: proteínas morfogenéticas ósseas (BMPs, sigla do inglês bone morphogenetic protein); fatores de crescimento para fibroblastos (FGFs, sigla do inglês fibroblast growth factor); proteínas Hedgehog (Hhs), proteínas wingless e int-related (Wnts) e fator de necrose tumoral (TNF, sigla do inglês tumor necrosis factor $)^{19}$. Apesar destas famílias distintas estarem envolvidas no desenvolvimento dentário, as BMPs são suficientes para a formação de dentina terciária ${ }^{20}$.

Alguns autores demonstraram ainda que a regeneração da polpa induzida por hidróxido de cálcio é mediada pela sinalização Notch célula-célula. Os resultados foram consistentes para afirmar que esta sinalização controla o destino de célulastronco provenientes da polpa, durante a regeneração da mesma ${ }^{15}$.

A família BMP faz parte da super-família TGF- $\beta$, composta de 25 fatores moleculares ${ }^{15}$. As BMPs podem ser divididas em 4 sub-famílias distintas: a primeira BMP-2 e 4; a segunda BMP-3 e BMP-3B, esta última também conhecida como fator de crescimento/diferenciação 10 (GDF-10, sigla do inglês growth/differentiation factor); a terceira BMPs 5, 6, 7 e 8 e a quarta GDFs 5, 6 e 7, também conhecidas por proteínas morfogenéticas 1,2 e 3 derivadas da cartilagem ${ }^{20}$. 
Em um estudo observou-se a expressão de BMP2, BMP-4, BMP-7, BMP-8, GDF-5 e GDF-6 através do método de hibridização e posterior análise com PCR nas polpas dentárias de incisivos de ratos. Os autores afirmaram que tais fatores são críticos para o desenvolvimento dentário e reparo pulpar. Não foi detectada a expressão de BMP-3 neste tecido ${ }^{21}$.

As BMPs também são expressas no epitélio estrelado do órgão do esmalte durante a fase de capuz e estão associadas com a diferenciação dos ameloblastos e odontoblastos ${ }^{20}$. O hormônio de crescimento pode induzir a expressão dessas BMPs durante a formação dentária ${ }^{12}$.

No início da morfogênese dentária, BMP-2, BMP4 e BMP-7 agem como importantes sinalizadores epiteliais que regulam a diferenciação do mesênquima derivado da crista neural em uma linhagem odontogência $^{12,28}$. Tais sinalizadores ainda determinam o número e a posição das cúspides dos dentes ${ }^{29}$.

Células da polpa dentária de porcos, cultivadas e tratadas com BMP-2, foram transplantadas para dentes despolpados de cães, com o objetivo de observar a diferenciação odontoblástica e a formação de dentina. A expressão do RNAm de sialofosfoproteínas da dentina (Dspp, sigla do inglês dentin sialophosphoprotein) e de metaloproteinases-20 da matriz (MMP-20, em inglês matrix metalloproteinases-20) confirmou a diferenciação de células pulpares em odontoblastos. Tal resultado comprovou o efeito estimulatório da BMP-2 para a formação de dentina ${ }^{10}$.

Foi demonstrado que a BMP-4 é expressa pelos pré-odontoblastos da bainha epitelial da raiz. Ademais, BMP-2 e BMP-7 são observadas em pré-odontoblastos e em odontoblastos durante um período relativamente curto de diferenciação, estando ausentes em odontoblastos maduros localizados na superfície da dentina coronária e radicular. BMP-3 foi localizada em ambas as células na área da raiz, mas não em odontoblastos diferenciados e secretores presentes na coroa dentária ${ }^{21}$.

Os membros da família FGF agem em diferentes momentos da odontogênese, desde o início do desenvolvimento dentário até a formação da última cúspide ${ }^{29}$. FGFs regulam a expressão de diversos genes e induzem a proliferação do mesênquima ${ }^{20}$.

Dentre os três membros da família Hedgehog (Hh) presentes nos vertebrados, Shh (sigla do inglês Sonic Hedgehog) é o único ligante Hh expresso nos dentes, sendo expresso durante o desenvolvimento inicial do germe dentário ${ }^{29}$.Com o objetivo de investigar a função da proteína Shh, pesquisadores bloquearam sua sinalização através de anticorpos neutralizantes e observaram que Shh possui duas funções no início da odontogênse. A primeira é durante a formação do botão dentário, ao estimular a proliferação epitelial, e a segunda é o aumento da sobrevida da célula epitelial durante o estágio de capuz ${ }^{4}$.

A maioria dos genes Wnt é expressa pelo epitélio dentário. Sugere-se que o Wnt7b interaja na sinalização Shh para estabelecimento dos limites entre o ectoderma oral e dentário, posicionando assim os locais de formação das estruturas dentárias ${ }^{29}$.

Sabe-se que os fatores de necrose tumoral (TNF) são cruciais na formação das cúspides dos molares ${ }^{29}$.

\section{APLICAÇÕES EM ODONTOLOGIA}

A terapia com células-tronco adultas geralmente é precedida pela compreensão de todas as suas propriedades, o controle de sua proliferação e os fatores que determinam sua diferenciação. A regeneração de um órgão dentário não é simples, pois seu desenvolvimento é determinado por interações complexas e inúmeros fatores de crescimento ${ }^{29} \mathrm{e}$, ainda, a diferenciação celular está ligada a mudanças morfológicas no decorrer da formação do germe dentário ${ }^{9}$. Tem sido proposta a utilização de células-tronco adultas em diversas áreas da Odontologia.

Em um estudo in vitro ${ }^{2}$, células-tronco mesenquimais obtidas da medula óssea de ratos foram isoladas e induzidas a se diferenciarem em células condrogênicas e osteogênicas através de estímulo com fator de crescimento tumoral (TGF- $\beta 1$ ). As mesmas foram encapsuladas em 
duas camadas de matriz composta por hidrogel de polietilenoglicol, moldadas em forma de côndilo de humanos. Esses moldes de acrílico foram implantados em dorsos de ratos imunodeficientes. Foi observada a formação de uma estrutura condilar após 8 semanas da implantação. Tal achado representa uma ferramenta útil para um futuro desenvolvimento de côndilos mandibulares através da engenharia tecidual ${ }^{2}$.

Em outra pesquisa, células-tronco mesenquimais provenientes de porcos foram isoladas, cultivadas em matriz de ácido poli-dl-láctico-coglicólico e incubadas por 10 dias em meio de cultura com suplemento osteogênico. Posteriormente a este período, as amostras foram transplantadas para defeitos ósseos mandibulares induzidos cirurgicamente e após 6 semanas realizou-se a análise histológica, clínica e radiográfica. Observou-se que os defeitos foram preenchidos com um tecido denso, semelhante ao osso, apresentando osteoblastos, osteócitos, vasos sanguíneos e osso trabeculado.

Inúmeros esforços têm sido direcionados para a regeneração periodontal. Laino et al. ${ }^{11}$ demonstraram a presença de células tronco-adultas no ligamento periodontal, com propriedade clonogênica e alta taxa proliferativa. Essas células foram estimuladas in vitro a diferenciarem-se em células tipo cementoblastos, através de um meio rico em L-ascorbato-2 fosfato, dexametasona e fosfato inorgânico; após 4 semanas observou-se acumulação cálcica, embora em menor proporção quando comparada com as células-tronco provenientes da medula óssea e da polpa dentária. A análise imunohistoquímica e Western blotting demonstraram que as células-tronco do ligamento periodontal expressaram uma variedade de marcadores cementoblásticos/osteoblásticos. Ao serem transplantadas para ratos imunocomprometidos as células formaram uma estrutura semelhante ao cemento/ligamento periodontal. Em defeitos criados cirurgicamente na área periodontal dos molares inferiores dos ratos, as células se integraram ao ligamento periodontal em duas das seis amostras e, ocasionalmente, uniram a superfície do osso alveolar ao dente. Esses achados implicam em uma possível função das células-tronco na regeneração tecidual periodontal, sendo necessários estudos mais aprofundados.

O objetivo da Odontologia conservadora é restaurar ou regenerar os tecidos dentários para manter a vitalidade, a função e a estética do dente. Gronthos et al. ${ }^{8}$ iniciaram estudos para isolar células-tronco da polpa dentária a partir de terceiros molares humanos impactados. Em meio de cultura composto por L-ascorbato-2-fosfato, glicorticóide e fosfato inorgânico, foi observada a capacidade de tais células formar em depósitos cálcicos in vitro. Após transplantação em ratos imunocomprometidos, as células-tronco pulpares exibiram habilidade de formar uma estrutura semelhante ao complexo dentina-polpa, composto de uma matriz de colágeno tipo I altamente organizada, perpendicular à camada tipo odontoblástica, e tecido fibroso contendo vasos sanguíneos, análogo à polpa encontrada em dentes humanos normais. Outros pesquisadores ${ }^{14}$ cultivaram o mesmo tipo celular em meio indutor de mineralização semelhante e observaram a formação de hidroxiapatita com pequenas quantidades de carbonatos, característicos de apatitas biológicas.

A matriz extracelular fosfoglicoprotéica não-colagênica (MEPE, sigla do inglês matrix extracellular phosphoglycoprotein) foi identificada recentemente no tecido dentário, tendo o peptídeo Dentonina derivado de sua seqüência gênica. A ação da Dentonina sobre as células-tronco da polpa foi avaliada ${ }^{13}$. Observou-se um aumento na taxa de proliferação dessas células, sendo possivel o uso deste peptídeo na regeneração da polpa em resposta a injúrias como traumas e cáries. São necessários mais estudos para aplicação in vivo desta terapia.

Em um estudo ${ }^{23}$, foi testada a capacidade do epitélio odontogênico de estimular células-tronco embriogênicas e mesenquimais, provenientes dos tecidos neural e medula óssea, a expressarem genes do desenvolvimento dentário e, assim, substituírem o mesênquima dentário na bioengenharia. Em amostras com células embriogênicas e neurais, observou-se a expressão de Dspp, gene expresso por odontoblastos, 
sugerindo que apesar de não haver formação dentária, há o estímulo para a diferenciação celular.

Um modelo de aplicação clínica da terapia endodôntica foi proposto por Nakashima ${ }^{18}$, baseado no cultivo, proliferação e diferenciação de células-tronco pulpares em odontoblastos, sua inserção em uma matriz moldada do preparo cavitário que apresente exposição pulpar e o posicionamento da matriz no dente. Assim haveria a proliferação dos odontoblastos e formação de dentina tubular funcional.

$\mathrm{Na}$ busca pela formação de um órgão dentário completo, foram desenvolvidos experimentos em ratos, utilizando primórdios da lâmina dentária ao invés de populações de células-tronco isoladas ${ }^{6,23}$. Isto evidencia uma dificuldade na manipulação de todos os fatores envolvidos no desenvolvimento de um órgão dentário. Além desta problemática é evidente a necessidade da inserção e funcionabilidade do órgão formado, de maneira que possa se integrar ao sistema estomatognático.

Pesquisadores observaram que células dentárias no estágio de botão, obtidas de ratos recém-nascidos, cultivadas in vitro durante 6 dias e transplantadas para dorsos de ratos imunocomprometidos, apresentaram resultados ótimos na formação de coroas dentárias maduras, com características muito semelhantes aos dentes formados naturalmente ${ }^{6}$. Para determinar se rudimentos dentários em fase de campânula poderiam formar um órgão dentário, quando transplantados para uma região desdentada da maxila em ratos adultos, foi desenvolvido um experimento ${ }^{23}$. Verificou-se que após 26 dias da transplantação houve formação de um dente ectópico, histologicamente normal, com presença de dentina, esmalte e um tecido similar ao ligamento periodontal. Sendo identificada pelos autores uma possibilidade de transplantação de primórdios dentários e seu subseqüente desenvolvimento em humanos. Tal possibilidade leva a discussões sobre a ética na experimentação com embriões em desenvolvimento ${ }^{23}$.

\section{CONSIDERAÇÕES FINAIS}

Existe um grande avanço nos experimentos com células-tronco adultas provenientes de tecidos bucais. O seu fácil acesso e o fato de não serem órgãos vitais constituem um atrativo para testes de praticidade e viabilidade de técnicas da bioengenharia. É possível que, num futuro próximo, se utilize da bioengenharia na terapia endodôntica e periodontal, apesar de, atualmente, a ciência se encontrar distante de desenvolver órgãos dentários completos a partir de células-tronco, devido aos mecanismos complexos da formação dentária.

\section{AGRADECIMENTOS}

Os autores agradecem à SempToshiba, pelo apoio constante ao Centro de Ortodontia e Ortopedia Facial Prof. José Édimo Soares Martins FOUFBA.

Enviado em: abril de 2006 Revisado e aceito: junho de 2006

\title{
Stem cells in Dentistry
}

\begin{abstract}
Introduction: there is great interest in developing techniques for manipulation of stem cells for the use in restoring organs and tissues. The effectiveness of bioengineering is based on the existence of stem cells, an extra cellular matrix and growth factors. Innumerous growth factors are involved in the development of dental organs, and this complexity of factors makes it extremely difficult to grow a complete organ, even though there are multiple essays reporting the formation of enamel and dentin from isolated stem cell, originating from dental pulp tissues. More recently, deciduous teeth have been used to extract stem cells from their pulp tissues. We know that these cells are highly proliferate. The recognition of the biological behavior of these cells and techniques used to isolate them is of great interest to dentists. Aim: the aim of this study was to review the current trends of research with stem cells in Dentistry and the factors implied for their practical and successful use.
\end{abstract}

Key words: Stem cells. Bioengineering. Dentistry research. 


\section{REFERÊNCIAS}

1. ABUKAWA, H.; SHIN, M.; WILLIAMS, W. B.; VACANTI, J. P.; KABAN, L. B.; TROULIS, M. J. Reconstruction of mandibular defects with autologous tissue-engineered bone. J Oral Maxillofac Surg, Philadelphia, v. 62, no. 5, p. 601-606, 2004.

2. ALHADLAQ, A.; MAO, J. J. Tissue-engineered neogenesis of human-shaped mandibular condyle from rat mesenchymal stem cells. J Dent Res, Alexandria, v. 82, no. 12, p. 951-956, 2003.

3. BATOULI, S.; MIURA, M.; BRAHIM, J.; TSUTSUI, T. W.; FISHER, L. W.; GRONTHOS, S.; ROBEY, P. G.; SHI, S. Comparison of stem-cell-mediated osteogenesis and dentinogenesis. J Dent Res, Alexandria, v. 82, no. 12, p. 976-981, 2003.

4. COBOURNE, M. T.; HARDCASTLE, Z.; SHARPE, P. T. Sonic hedgehog regulates epithelial proliferation and cell survival in the developing tooth germ. J Dent Res, Alexandria, v. 80, no. 11, p. 1974-1979, 2001

5. DENG, M.; SHI, J.; SMITH, A. J.; JIN, Y. Effects of transforming growth factor beta1 (TGFbeta-1) and dentin non-collagenous proteins (DNCP) on human embryonic ectomesenchymal cells in a three-dimensional culture system. Arch Oral Biol, Oxford, v. 50, no. 11, p. 937-945, 2005.

6. DUAILIBI, M. T.; DUAILIBI, S. E.; YOUNG, C. S.; BARTLETT, J. D. VACANTI, J. P.; YELICK, P. C. Bioengineered teeth from cultured rat tooth bud cells. J Dent Res, Alexandria, v. 83, no. 7, p. 523$528,2004$.

7. GRONTHOS, S.; BRAHIM, J.; LI, W.; FISHER, L. W.: CHERMAN, N.; BOYDE, A.; DENBESTEN, P.; ROBEY, G. P.; SHI, S. Stem cell properties of human dental pulp stem cells. J Dent Res, Alexandria, v. 81, no. 8, p. 531-535, 2002.

8. GRONTHOS, S.; MANKANI, M.; BRAHIM, J.; GEHRON ROBEY, P.; SHI, S. Postnatal human dental pulp stem cells (DPSCs) in vitro and in vivo. Proc Natl Acad Sci USA, Washington, D. C., v. 97 , no. 25 , p. $13625-13630,2000$

9. HARADA, H.; MITSUYASU, T.; TOYONO T.; TOYOSHIMA, K. Epithelial stem cells in teeth. Odontology, Tokyo, v. 90, no. 1, p. 1-6, 2002

10. IOHARA, $K$ : NAKASHIMA, $M$ : ITO, M.: ISHIKAWA, M.: NAKASIMA, A.; AKAMINE, A. Dentin regeneration by dental pulp stem cell therapy with recombinant human bone morphogenetic protein 2. J Dent Res, Alexandria, v. 83, no. 8, p. 590595,2004 .

11. LAINO, G.; D'AQUINO, R.; GRAZIANO, A.; LANZA, V.; CARINCl, F.; NARO, F.; PIROZZI, G.; PAPACCIO, G. A new population of human adult dental pulp stem cells: a useful source of living autologous fibrous bone tissue (LAB). J Bone Miner Res, Washington, D. C., v. 20, no. 8, p. 1394-402, 2005

12. LI, H.; BARTOLD, P. M.; ZHANG, C. Z.; CLARKSON, R. W. YOUNG, W. G.; WATERS, M. J. Growth hormone and insulinlike growth factor $\mathrm{i}$ induce bone morphogenetic proteins 2 and 4: a mediator role in bone and tooth formation? Endocrinology, Chevy Chase, v. 139, no. 9, p. 3855-3862, 1998.

13. LIU, H.; LI, W.; GAO, C.; KUMAGAI, Y.; BLACHER, R. W.; DENBESTEN, P. K. Dentonin, a fragment of MEPE, enhanced dental pulp stem cell proliferation. J Dent Res, Alexandria, v. 83, n. 6 , p. 496-499, 2004
14. LIU, $\mathrm{H} \cdot \mathrm{LI}, \mathrm{W} \cdot \mathrm{SHI}, \mathrm{S}$ : HABELITZ, $\mathrm{S}$ : GAO, C : DENBESTEN, P. MEPE is downregulated as dental pulp stem cells differentiate. Arch Oral Biol, Oxford, v. 50, no. 11, p. 923-928, 2005.

15. LOVSCHALL, H.: TUMMERS, M.; THESLEFF, I.; FUCHTBAUER, E. M.; POULSEN, K. Activation of the Notch signaling pathway in response to pulp capping of rat molars. Eur J Oral Sci, Copenhagen, v. 113, no. 4, p. 312-317, 2005.

16. MIURA, M.; GRONTHOS, S.; ZHAO, M.; LU, B.; FISHER, L. W. ROBEY, P. G.; SHI, S. SHED: stem cells from human exfoliated deciduous teeth. Proc Natl Acad Sci USA, Washington, D.C., v. 100, no. 10, p. 5807-5812, 2003.

17. MOONEY, D. J.; POWELL, C.; PIANA, J.; RUTHERFORD, B. Engineering dental pulp-like tissue in vitro. Biotechnol Prog, New York, v. 12, no. 6, p. 865-868, 1996.

18. NAKASHIMA, M. Bone morphogenetic proteins in dentin regeneration for potential use in endodontic therapy. Cytokine Growth Factor Rev, Oxford, v. 16, no. 3, p. 369-376, 2005.

19. NAKASHIMA, M.; AKAMINE, A. The application of tissue engineering to regeneration of pulp and dentin in Endodontics. J Endod, Baltimore, v. 31, no. 10, p. 711-718, 2005.

20. NAKASHIMA, M.; REDDI, H. The application of bone morphogenetic proteins to dental tissue engeneering. Nat Biotechnol New York, v. 21, no. 9, p. 1025-1032, 2003

21. NAKASHIMA, M.; TOYONO, T.; MURAKAMI, T.; AKAMINE, A. Transforming growth factor-beta superfamily members expressed in rat incisor pulp. Arch Oral Biol, Oxford, v. 43, no. 9 , p. 745-751, 1998

22. ODORICO, J. S.; KAUFMAN, D. S.; THOMSON, J. A. Multilineage differentiation from human embryonic stem cell lines. Stem Cells, Basel, v. 19, no. 3, p. 193-204, 2001.

23. OHAZAMA, A.; MODINO, S. A.; MILETICH, I.; SHARPE, P. T. Stem-cell-based tissue engineering of murine teeth. J Dent Res, Alexandria, v. 83, no. 7, p. 518-522, 2004.

24. RISBUD, M. V.; SHAPIRO, I. M. Stem cells in craniofacial and dental tissue engineering. Orthod Craniofacial Res, Oxford, v. 8 , no. 2, p. 54-59, 2005

25. SEO, B. M.; MIURA, M.; GRONTHOS, S.; BARTOLD, P. M.; BATOULI, S.; BRAHIM, J.; YOUNG, M.; ROBEY, P. G.; WANG, C. Y.; SHI, S. Investigation of multipotent postnatal stem cells from human periodontal ligament. Lancet, London, v. 364, no. 9429, p. 149-155, 2004

26. SHI, S.; BARTOLD, P. M.; MIURA, M.; SEO, B. M.; ROBEY, P. G.; GRONTHOS, S. The efficacy of mesenchymal stem cells to regenerate and repair dental structures. Orthod Craniofac Res, Oxford, v. 8, no. 3, p. 191-199, 2005

27. SHI, S.; ROBEY, P. G.; GRONTHOS, S. Comparison of human dental pulp and bone marrow stromal stem cells by cDNA microarray analysis. Bone, New York, 29, no. 6, p. 532-539, 2001.

28. YAMASHIRO, T.; TUMMERS, M.; THESLEFF, I. Expression of bone morphogenetic proteins and Msx genes during root formation. J Dent Res, Alexandria, v. 82, no. 3, p. 172-176, 2003.

29. ZHANG, Y. D.; CHEN, Z.; SONG, Q.; LIU, C.; CHEN,Y. P. Making a tooth: growth factors, transcription factors and stem cells. Cell Res, Beijing, v. 15, no. 5, p. 301-316, 2005.

\section{Endereço de correspondência}

Ana Prates Soares

Rua Araújo Pinho n. 62, $7^{\circ}$ andar, Bairro Canela

CEP: 40.110-150 - Salvador/BA

E-mail: prates_ana@yahoo.com.br 